\title{
811.163.41'367.625
}

811.163.41'367.332.7

https://doi.org/10.18485/sj.2021.26.1.11

НАТАША Р. МИЛИВОЈЕВИЪ

Универзитет у Новом Саду

Филозофски факултет
Оригинални научни рад

Примљен: 13. 10. 2020.

Прихваћен: 12. 1.2021.

\section{О АНАЛИТИЧКИМ ПРЕДИКАТИМА СА ГЛАГОЛОМ КРЕНУТИ У СРПСКОМ ЈЕЗИКУ: ЛЕКСИЧКО-ПРОЈЕКЦИОНИСТИЧКИ ПРИСТУП}

У раду се анализира глагол кренути у својству предикатског израза који је обухваћен аналитичким предикатом. Показано је да овај глагол у српском језику поред самосталног, лексичког испољава још два додатна значења: фазно почетно и модалитетно волитивно значење. Будући да се ова два значења изражавају готово идентичним синтаксичким структурама, предложени оквир анализе је лексичко-пројекционистички модел (Левин 1993). Основни теоријски принцип модела који смо применили у раду јесте да је значење глагола кључ његовог синтаксичког потенцијала, те да се глаголи могу сврстати у семантичке класе на основу устаљеног синтаксичког понашања унутар одређеног језичког система. Скуп значења глагола кренути описан је прво на нивоу лексикона, а потом су та значења у склопу аналитичких предиката анализирана на нивоу конструкције. На нивоу лексикона формирана је класа семантички непотпуних глагола у српском језику којима припада и глагол кренути са фазним и модалитетним значењима. Дефинисане су припадајуће структуре аргумената за појединачна значења глагола кренути, као и њихове алтернације и/или варијације које су потом обједињене повезаном лексичком спецификацијом тог глагола. На нивоу конструкције, аналитички предикат се посматра у оптималном контексту, при чему се анализира семантички и синтаксички допринос не само глаголског дела аналитичког предиката, већ и осталих конституената, на пример субјекта, 
адвербијала, предлошко-падежне допуне и сл. Закључци приказани у раду проверени су на корпусу реченичних примера којима су обухваћене релевантне контекстуализације глагола кренути у модерном језику.

Кључне речи: глагол кренути, аналитички предикат, структура аргумената, лексичко-пројекционистички модел, фазно значење, модалитетно значење, конструкција

\section{1. УВОДНЕ НАПОМЕНЕ}

У раду се анализира употреба глагола кренути у оквиру аналитичких предиката ${ }^{1}$ са денотацијама фазе и модалности. У погледу термина аналитички предикат усвајамо дефиницију према Антонић (2000), и Пиперу и сарадницима (2005), где се степен сложености предикације примарно детерминише на основу синтаксичке, а додатно и на основу морфолошке сложености глаголских облика који улазе у његов састав. ${ }^{2}$ Глаголски део аналитичког предиката нема самостално лексичко значење. За потребе нашег истраживања, аналитички предикат смо дефинисали као синтаксичко-семантичку конструкцију која обухвата фазни/модални глагол са обавезном семантичко-синтаксичком допуном (инфинитив, конструкција ДА+немобилни презент и у случају аналитичких предиката са фазним глаголом, именска допуна са и без предлога).

Глагол кренути се у српском језику јавља као самостални лексички глагол са значењем (просторног) кретања, али може испољити и друга, додатна значења онда када се користи као глагол без самосталног лексичког значења и тада на позицији комплемента везује обавезну семантичко-синтаксичку допуну. У овом раду показаћемо да се глагол кренути у српском језику може јавити у оквиру два типа аналитичких предиката и то са фазним и са модалитетним значењем. Када се јавља унутар фазног аналитичког предиката, кренути означава почетак радње, док се у оквиру модалног/модалитетног аналитичког предиката овај глагол користи са модалитетним значењима „покушати/ покушавати, намерити/намеравати” која су блиска волитивном³ значењу (или у општим терминима динамичкој модалности $)^{4}$ и њима се исказује вољност, решеност или намера да се радња иницира или започне. Колико нам је познато, модалитетном значењу глагола кренути до сада у србистици није посвећено много пажње, а прегледом литературе (Мразовић/Вукадиновић 1990, Мразовић 2009, Степанов, Озер 2016 итд.) установили смо да листе модалитетних

${ }^{1}$ Термин предикат се односи на предикатски израз, не на синтаксичку функцију нити на конститутивни део пропозиције.

${ }^{2}$ Разлика између аналитичког и сложеног предиката је у томе што сложени предикат садржи најмање два морфолошки сложена глагола.

${ }_{3}^{3}$ У троделним класификацијама модалних значења, оваква употреба модала спада у динамичку модалност.

43а детаљнију дискусију погледати рад П. Новакова (2015). 
глагола не укљујучују кренути са модалитетним значењима иако су она у српском језику доста честа. Са друге стране, ово и није тако изненађујуће јер су модалитетни глаголи изразито динамична и флуидна отворена класа која се може обогаћивати додавањем нових чланова. Важно је напоменути и то да се обе додатне употребе глагола кренути сврставају у маргиналне или атипичне (кренути је атипични фазни глагол, док је намерити модалитетни, а самим тим је тако и са кренути са значењем покушаја и/или намере), због чега их није лако разграничити само „површинским” посматрањем, већ је за што потпунији теоријски опис употребе и значења глагола кренути у српском језику, потребно применити теоријски модел који има довољно јак експланаторни потенцијал да системски, доследно и на основу дефинисаног броја формалних параметара опише, повеже и објасни постојеће употребе и значења тог глагола у модерном језику. Предложени теоријски модел анализе је лексичко-пројекционистички модел (Левин 2000), чија је основна идеја да је значење глагола као „генератор” структуре аргумената у лексикону кључ за његово синтаксичко понашање, те да се, сходно томе, глаголи могу сврстати у семантичке класе на основу дефинисаног и карактеристичног синтаксичког понашања.

Неколико је важних разлога за примену оваквог модела анализе. Како наводе Степанов и Озер (2016), синтаксички статус семантички непотпуних глагола у србистици није до краја доследно разрешен, а понекад се чак у оквиру истог уџбеника или граматике износе потпуно супротни закључци о овом питању. ${ }^{5,6}$ У погледу семантике, фазни и модални глаголи нису јасно разграничени, нити су њихови спискови потпуни. Коначно, Антониић (2000: 95) износи следећу тврдњу: „Иначе, начелно проблем семантичке потпуности / непотпуности (разуме се не само када је у питању допуњавање глаголске лексеме, односно не само када је у питању допуњавање глаголском лексемом), тачније утврђивање прецизних критерија за разликовање (уколико је то уопште

5 За детаљну дискусију погледати рад Степанова и Озер 2016.

${ }^{6}$ Навешћемо овде само један пример према Степанову и Озер (2016). У српском најобимнијем универзитетском уџбенику из синтаксе, „Савременом српскохрватском језику II” Михаила Стевановића говори се о сложеним глаголским предикатима уз напомену да је такав предикат састављен из „два лична глаголска облика када, рецимо, сам један глагол у личном глаголском облику не именује одређену радњу или стање, него му је потребно додати други који глагол" (Стевановић 1974: 36). Стевановић додаје како је „овакав предикат састављен од глагола непотпуног значења, какви су модални глаголи: моћи, морати, требати, вредети, смети, умети и сл., као и глаголи који означавају почетак, настављање или прекид радње: почети, стати или узети, престати, наставити, продужити, прекинути и инфинитива или презента с везником да" (Стевановић, 1974: 37). Другим речима, аутор сврстава фазне и модалне глаголе у исту групу (семантички несамосталних) глагола који се јављају са комплементом, што је у сагласју и са нашом анализом, али онда на другом месту у истом уџбенику, тврди како „модални глагол хтети, као и желети, „целу од њега зависну реченииу у функцији допуне чини модалном, па и онда, дакако, када је та допуна облик инфинитива" (Стевановић 1974: 761). 
могуће, обзиром на, по свој прилици, градуелну природу ове појаве), један је од озбиљних општелинвистичких теоријских проблема чије решавање тек предстоји.” Приступ предмету истраживања какав предлажемо у овом раду треба да, у оном сегменту који се тиче релевантних употреба глагола кренути, допринесе свеобухватнијем теоријском опису фазних и модалних глагола у савременом српском језику.

\section{2. ТЕОРИЈСКИ ОКВИР ИСТРАЖИВАЮА}

Централни и суштински најважнији теоријски принцип модела који смо применили у овм раду јесте да се глаголи могу сврстати у семантичке класе на основу устаљеног синтаксичког понашања. Додатно, синтаксичко понашање глагола проистиче из интеракције лексичког значења глагола и његове структуре аргумената. Хал и Кајзер (1987) чак износе тврдњу да изворни говорник неког језика уме да интуитивно предвиди граматичко (синтакисчко) понашање глагола на основу његовог значења. Пошто је то тако, следи да је за укупну семантичку карактеризацију глагола неопходно правилно описати скуп фактора који га у лексикону „репрезентују”. Ово никако није исто што и, на пример, површински лексикографски попис значења. Према лексичко-пројекционистичком моделу лексикона, глагол пројектује и везује аргументе, који чине синтаксичке обрасце, формирајући тако конструкције у којима се тај глагол доследно и устаљено појављује. Те конструкције, или консталације аргумената, управо и представљају формални критеријум према ком се глаголи сврставају и групишу у семантичке класе. Из овога даље проистиче став да укупна семантичка интерпретација глаголског значења настаје у међуодносу (лескичке) семантике и синтаксе, уз потенцијални додатак прагматичко-комуникативне компоненте, тј. употребне „снаге” одређеног глагола.

Као што је већ истакнуто, семантички непотпуни, или непунозначни глаголи представљају нарочито озбиљан изазов за лингвистичку теорију уопште. Они учествују у организацији смисаоне целине исказа, при чему у исказ уносе своје модификаторске способности. Крстић (2016: 15) наводи да су непунозначни глаголи речи са потпуним или делимичним губитком значења, при чему се губитак лексичког значења може објаснити „изменом односа између лексичке и граматичке семантике унутар речи". У зависности од функционалних услова, непунозначни глаголи испољавају различит степен губитка лексичког значења због чега су „границе између пунозначних и непунозначних глагола веома танке и покретне, што и чини дату групу глагола отвореном за допуњавање новим речима” (Крстић 2016: 16).

Непунозначни фазни и модални глаголи нису добили исцрпан опис у студији Класе и алтернације глагола у енглеском језику, Бет Левин (1993). 
Сама ауторка студије иначе наглашава да је овакав теоријски модел тек први, пионирски покушај да се на иновативан начин опише значење глагола који припадају лексикону енглеског језика, те да су ревизије неких класа пожељне и потребне, као и додавање нових. У међујезичкој перспективи, применљивост оваквог модела прикладна је пре свега са теоријског становишта, а приказана идеја теоријског моделовања може се применити на различите природне језике (што је до сада и учињено за велики број њих), уз већа или мања (не) подударања описаних класа глагола.

Наиме, у оквиру студије Класе и алтернаиије глагола у енглеском језику, енглески аспектуални глаголи кратко су описани у одељку 55 (Левин 1993: 274-275), док модални глаголи нису издвојени као посебна класа. ${ }^{7}$ Остаје нејасно по ком критеријуму су модали потпуно изостали (осим по критеријуму непотпуног значења, но онда би требало да су и фазни глаголи изостали!), осим претпоставке да је њихов исцрпан семантички и синтаксички опис већ дат у великом броју студија написаних на енглеском језику. Овај закључак намеће се и због тога што је одељак посвећен фазним глаголима изразито кратак, и тиче се само присуства/одсуства синтаксичке дијатезе ${ }^{8}$ уз опаску ауторке да је комплементација фазног глагола детаљно описана другде у литератури те стога неће бити предмет даље анализе. Левин не узима у обзир тип фазе на коју се односи одређени аспектуални глагол (наступ, почетак, нуклеус, завршетак кода ${ }^{9}$ ) па су тако, на пример, енглески глаголи complete (обавити), discontinue (прекинути), и initiate (започети) чланови исте поткласе јер сва три глагола имају искључиво транзитивну употребу. Овакав приступ значајно се разликује од већине досадашњих студија о аспектуалним глаголима у србистици (којих је, опет, релативно мали број ${ }^{10}$ ), а које су махом засноване на почетној, средишњој и завршној фазној семантици глагола са једне и одговарајућег сегментирања догађаја означеног комплементом са друге стране.

У наредном одељку рада ћемо показати како се лексичко-пројекционистички модел анализе према поставкама Бет Левин може применити како бисмо сачинили семантичку класу глагола која обухвата фазне и модалне глаголе у српском језику.

${ }^{7}$ Поједини модалитетни глаголи расути су по различитим класама које испољавају блиско синтаскичко понашање, нпр. глагол желети (енглески want) припада класи глагола жеље (енглески Verbs of Desire), а такав је случај и са осталим модалним/модалитетним глаголима. (Левин 1993: 194)

${ }^{8}$ Термин је преузет од Пипера и сарадника (2005:608): у ширем смислу, дијатеза је синтаксичка конверзија која укључује сваки однос између аргумената у семантичкој структури реченице с једне стране, и начина њиховог изражавања на формално-синтаксичком плану са друге стране (однос агенса и пацијенса, транзитивност/прелазност, пасивизацију, итд.)

${ }^{9}$ Према Фрид 1979.

${ }^{10} \mathrm{O}$ овоме детаљно говори Кљакић (2020). 


\section{3. КЛАСА СЕМАНТИЧКИ НЕПОТПУНИХ ГЛАГОЛА У СРПСКОМ ЈЕЗИКУ}

У српском језику, непунозначни глаголи обухватају копуле и модификаторе, при чему група копулативних глагола може додатно да се раслоји на (праве) копуле и семикопуле, ${ }^{11}$ док група лексички несамосталних, тј. непунозначних модификатора обухвата фазне и модалне глаголе. Поврх тога, непунозначни глаголи чине лексичко поље са јасно израженим језгром и периферијом. Како наводи Крстић (2016: 15-16), језгро поља чини не тако велики слој речи са ослабљеним лексичким значењем, а периферију представља „огромна група речи прелазног карактера, чији је степен десемантизације посве различит". Крстић даље напомиње да се слабљење лексичке семантике и јачање валенцијских могућности непунозначних глагола испољава у њиховим функционалним специфичностима, а нарочито у неспособности да врше функцију самосталног предиката у реченици, због чега се они могу користити искључиво у саставу аналитичких типова предиката. Функционална својства непунозначних глагола најпотпуније се испољавају у типичним контекстима због чега се утврђивање њиховог значења ослања на строго дефинисан круг синтаксичких концепата.

Пошто је то тако, следи да је методологија модела према Левин (1993) изразито прикладна за опис и анализу семантички несамосталних глагола. Узвратно, непотпуност значења са једне и доследно синтаксичко понашање са друге стране, чине ове глаголе изразито погодним пољем које се може доследно дефинисати и објаснити управо применом лексичко-пројекционистичког модела. Као што смо раније поменули. када је реч о аспектуалним глаголима у енглеском језику, сама ауторка студије се у опису ове класе глагола руководила искључиво њиховом карактеристичном синтаксом. Оно што је новина у односу на њен приступ, јесте да ћемо овде предложити да, управо због блиског синтаксичког понашања (са минималним алтернацијама/варијацијама), у српском језику фазни и модални глаголи треба да чине јединствену семантичку класу. Идеја о томе да се фазни и модални глаголи сврстају у исту групу глагола и анализирају према заједничким формалним и функционалним карактеристикама није нова, такав приступ до сада су у србистици, између осталих, применили Антонић 2000, Пипер и сарадници 2005, Крстић 2016. и други. Поновићемо овде да смо аналитички предикат за потребе нашег истраживања дефинисали као синтаксичко-семантичку конструкцију која обухвата фазни или модални/

${ }^{11}$ Крстић (2016) овде додаје и глаголе које назива квазикопулативним глаголима, а то су глаголи који у одређеним ситуацијама могу да се десемантизују и постану саставни део аналитичких глаголских структура. 
модалитетни ${ }^{12}$ глагол са обавезном семантичко-синтаксичком допуном, која је најчешће глагол у инфинитиву, конструкција ДА+немобилни презент и, у случају аналитичких предиката са фазним глаголом, то је још и именска допуна са и без предлога, при чему се овакве допуне не јављају уз модалне глаголе.

Формирању предложене класе семантички непотпуних глагола приступили смо на следећи начин: као полазну методолошку основу усвојили смо општи, прототипски преглед семантичке класе глагола према Бет Левин (1993) који укључује наслов (назив класе), релевантне референце, уводну семантичку карактеризацију глагола, и потом називе и описе поткласа, уколико оне постоје. Свака поткласа даље треба да се састоји од списка глагола који јој припадају и описа релевантних синтаксичких образаца у којима се ти глаголи јављају, и уколико је потребно, она треба да садржи и завршни коментар. Спискове глагола који су ушли у састав предложене класе смо, уз минимална прилагођавања, преузели од Мразовић/Вукадиновић (1990) и Крстић (2016) (модалне) и Антонић (2000) и Пипера и сарадника (2005) (фазне), по критеријуму потпуности и образложености. Поткласи модалитетних глагола додали смо глагол кренути са волитивним значењем. У другој методолошкој фази провере материјала, направили смо, увидом у релеватну литературу почетни списак значајних синтаксичких карактеристика семантички непотпуних глагола које смо потом проверили на корпусу. Напомињемо да је класа глагола коју овде предлажемо сачињена примарно због описа значења и употребе глагола кренути, ${ }^{13}$ нонастојали смо да у њу унесемо све податке релевантне за укупни преглед укључених глагола. Предложени наслов класе је Семантички непотпуни глаголи, а њен предложени састав обухвата поткласу копулативних глагола и поткласу (фазних и модалних) модификатора. Приказујемо је овде:

\section{Семантички непотпуни глаголи}

I. Семантички непотпуни копулативни глаголи: копуле и семикопуле ${ }^{14}$

II. Семантички непотпуни модификатори: фазни и модални

Чланови ове групе глагола посматрају се као семантички и синтаксички несамостални, што значи да се обавезно јављају са семантичко-синтаксичком допуном, тј. са комплементом, у функцији модификатора значења лексички самосталног глагола. Чланови фазне и модалне класе могу се узајамно комбиновати на синтаксичком нивоу уколико је први елемент конструкције модални глагол, нпр. Они морају да крену//Они хоће да почну. Синтаксичка комбинација

${ }^{12}$ Аналитички предикат може да обухвати и копуле и семикопуле, али се такве конструкције не разматрају у овом истраживању.

${ }^{13}$ Требало би проверити и понашање, на пример, других атипичних фазних глагола, али такво и друга слична истраживања остављамо за неку будућу прилику.

${ }^{14}$ Ово истраживање не обухвата анализу овог дела семантичке класе непотпуних глагола. 
са фазним глаголом као првим елементом могућа је за неке глаголе, углавном уз значајне стилске и прагматичке импликације: Почео је/npecmaо je да хоће// Почела je/nрестала је да неће. Такође, два фазна глагола се не могу јавити заједно, док два модална могу.

Референце: Стевановић 1969, Ивић 1970, Хлебец 1990, Мразовић/Вукадиновић 1990, Станојчић/Поповић 1994, Мразовић 2009, Антонић 2000, Пипер и др. 2005, Радовановић 1990, Пипер/Клајн 2013, Крстић 2016.

I Фазни глаголи: почињати:почети, настављати:наставити, престајати:престати, завршавати:завршити

Опис: Ови глаголи означавају започињање, прекидање или настављање радње, тј. њима се означава одређена етапа, односно фаза у трајању глаголског догађаја. У релевантној литератури фазни глаголи називају се још и аспектуалним глаголима или аспектуализаторима. Поред типичних, постоје и атипични аспектуализатори у српском језику, што значи да се они налазе у подсистему укупне класе српских фазних глагола, и то су глаголи кренути, узети и стати. ${ }^{15}$

\section{Својства:}

Јован почиње/наставља/престаје/*завршава да плаче.

Јован почиње/наставља/престаје/*завршава плакати.

*перфективна допуна

*Јован је почео/наставио/престао/завршио да заплаче.

*Јован је почео/наставио/престао/завршио заплакати.

Синтаксичка дијатеза

Јован је почео/наставио/завршио састанак/престао са састанком.

Састанак је почео/се наставио/је престао/се завршио.

именска допуна/предлошко-падежна синтагма

Јован почиње/наставља/престаје/завршава с плакањем

Јован крену да плаче//Јован крену плакати//Јован крену с плакањем

Јован узе да плаче//Јован узе плакати//*Јован узе с плакањем.

Јован стаде да плаче//Јован стаде плакати//*Јован стаде с плакањем.

Коментар: Фазни глаголи везују следеће структуре на позицији допуне: инфинитив, конструкцију ДА+немобилни презент, именицу у номинативу, акузативу или инструменталу са предлогом или без предлога. Сви типични фазни глаголи, са изузетком глагола завршити:завршавати могу да се јаве са свим прототипским допунама; завршити је изузетак јер се овај глагол својом примарном лексичком семантиком дефинише као глагол који се по правилу односи само на последњи сегмент радње који је немогуће изоловати из имен-

\footnotetext{
${ }^{15}$ Списак атипичних фазних глагола преузет је од Пипера и сарадника (2005: 313).
} 
ске структуре на позицији допуне. ${ }^{16}$ Чланови ове групе глагола по правилу се јављају са имперфективним комплементом. У морфолошкој структури фазних глагола може се уочити морфема која инхерентној глаголској семантици придодаје обележје имперфективност/перфективност, при чему је имперфективност пунозначног глагола обавезна. Предикација састављена према оваквом моделу на нивоу реченице сматра се функционално јединственом, али формално и семантички комплексном јер садржи два елемента при чему фазни глагол (први елемент) има улогу модификаторске семе, тј. он модификује семантику пунозначног глагола (другог елемента) који има улогу основне, инхерентне лексичке семе. Из овога следи да „фаза реализације једне предикације може бити идентификована само уколико се предикацијски денотат перцепира као ентитет реалности с обележјем дуративности - трајање (+) (што се у начелу може повезати с имперфективношћу), а да то не може бити случај уколико се предикацијски денотат перцепира као ентитет реалности с обележјем резултативности - циљ (+) (што је карактеристика перфективности)" (Антонић 2000: 96).

Додатно, поједини атипични фазни глаголи трпе ограничења у погледу структуре комплемента због примеса других, нефазних значења која се појачавају на нивоу конструкције са именском допуном, било да је реч о њиховом примарном значењу (стати, узети), или о примеси модалног значења, нпр. интенција, волитивност и сл. Фазни глаголи имају обавезну лескичко-семантичку пресупозицију.

II Модални глаголи: моћи, хтети, морати, смети, умети, требати, волети и желети.

Опис: Ови глаголи на семантичком плану денотирају могућност/способност (моћи, смети), волитивност (хтети), пожељну облигаторност (требати), те нужну облигаторност (морати) агенса да врши/изврши одређену радњу која без обзира на временску сферу остаје нереализована. ${ }^{17}$ Осим основних модалних глагола, постоји и скуп тзв. модалитетних глагола и то су: бојати се („не усудити се не усуђивати се”), доспети/доспевати („стићи, наћи време”), дрзнути се („непромишљено се осмелити / усудити се”), гледати (,трудити се, покушати”), имати („намеравати”), канити („намеравати”), мислити („намеравати”), намеравати (,имати намеру”), намислити/наумити („намеравати”), настојати (,„потрудити се”), наумити (,„решити се”), обичавати (,имати обичај”),

16 За додатну аргументацију која се тиче временског односа управног глагола и комплемента видети Антонић 2000.

${ }^{17}$ Антонић (2000) напомиње да Ивић (1970) у контексту разматрања појаве немобилног презента у различитим синтаксичко-семантичким структурама његово јављање уз модалне глаголе доводи у везу са семантичким обележјем експектативности које је присутно на дубинској структури, а које је у непосредној вези с обележјем реализованост радње (-). 
оклевати („не одлучивати се”), плашити се („не усуђивати се”), правити се („начинити се као да...”), прибојавати се („не усуђивати се”), претварати се („приказати се друкчијим”), смерати („намеравати”), стићи („,доспети”), успети („доспети”), усудити се/усуђивати се („осмелити се, одважити се”), волети (,имати обичај”), заинатити се („бити тврдоглав”), знати („имати обичај”), кренути (,имати намеру”, „намерити”, „желети”, „хтети”, „покушати”). ${ }^{18}$

\section{Својства:}

Јован може да пева/певати.

Јован може да запева/запевати.

*именска допуна/предлошко-падежна синтагма

* Јован хоће с певањем.

Јован има да учи/учити.

Јован гледа да победи/победити.

Јован гледа да увек победи. ${ }^{19}$

Јован може и хоће да ради//да уради.

Коментар: Модални глаголи као и фазни на позицији допуне везују инфинитив и конструкцију ДА+немобилни презент, али се, за разлику од фазних глагола, не могу јавити уз именице са и без предлога. „Као и у случају предикације с фазним глаголом, и овде је носилац потребних граматичних значења (лице, број, род, време, начин), односно носилац финитности први глаголски елемент - модални глагол”. (Антонић 2000: 98). Оба глаголска дела предикације по правилу имају исти агенс. За разлику од фазних глагола, пунозначни глагол у допуни може бити и имперфективног и перфективног вида.

\section{4. ЛЕКСИЧКА СПЕЦИФИКАЦИЈА ГЛАГОЛА КРЕНУТИ НА НИВОУ ЛЕКСИКОНА}

Већ смо претходно утврдили да кренути у модерном језику испољава три (почетна) значења од којих је прво лексички самостално, док су друга два лексички и синтаксички несамостална, и то су фазно и модалитетно значење. ${ }^{20}$ У оквиру класе семантички непотпуних фазних и модалних глагола коју смо

${ }^{18}$ Подкласа модалитетних глагола сачињена је на основу Мразовић/Вукадиновић 1990, с тим да смо том списку додали глагол кренути са значењем намере.

${ }^{19}$ Пипер и Клајн (2013: 498) као једину разлику између модалних и модалитетних глагола наводе тврдњу да код модалитетних глагола одредбе могу да стоје унутар конструкције ДА+презент, док код модалних глагола то није могуће: *Он мора да данас путује//Он мора данас да путује.

${ }^{20}$ Наше истраживање нема за циљ формирање лексикографског приказа свих површинских значења глагола кренути; циљ нам је да повежемо она из којих на нивоу конструкције или у оптималном контексту „извиру” сва остала. 
установили у претходној фази истраживања, кренути са додатним значењима члан је обе поткласе семантички несамосталних модификатора. Такође, на основу исте те класе фазних и модалних модификатора, сада можемо да прикажемо укупну лексичку спецификацију глагола кренути. Лексичка спецификација је скуп свих значења једног глагола, независно од тога да ли се тај глагол везује само за једну, или је истовремено члан две или више семантичких класа. ${ }^{21}$ Наиме, лексички самостални глагол кренути припада класи глагола кретања, док лексички несамостални глагол кренути спада у семантички несамосталне модификаторе:

i. КРЕНУТИ, $\left(+\right.$ АРГ $\left._{1}\right)=$ кретати се, ставити у покрет (самостално лексичко значење)

ii. $\mathrm{KPEHУТИ}_{2 \phi}\left(+\mathrm{APГG}_{2 \phi}\right)=$,почети” (фазно значење)

iii. КРЕНУТИ, ${ }_{3 м}\left(+\mathrm{AP}_{3 м}\right)=$,покушати/покушавати//намерити/намеравати" (модалитетно значење)

Ова значења могуће је обухватити јединственом лексичком спецификацијом која је приказана на слици 1:

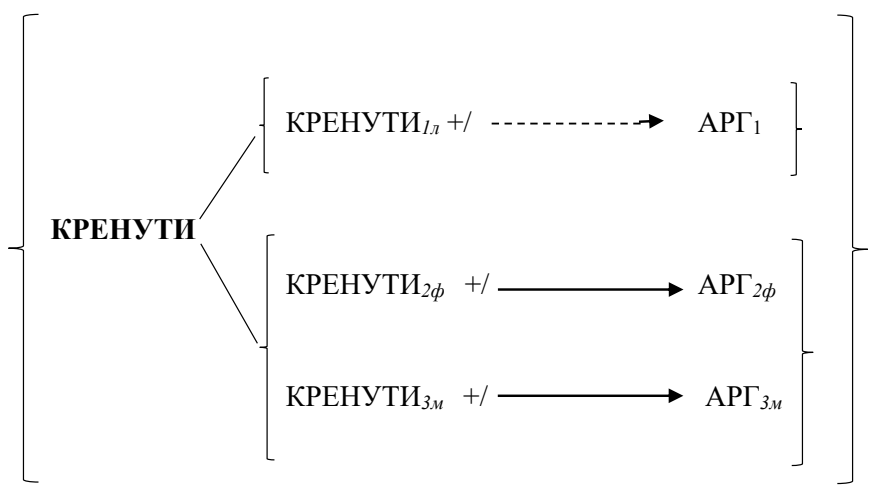

\section{Слика 1.}

Као што је се види из приказа на слици 1 кренути на нивоу лексикона пројектује три структуре аргумената на основу којих се дефинишу његова могућа значења. У реализацији лексичког значења „кренути, покренути” глагол $\kappa_{\text {кенути }}$ је лексички самосталан те му није неопходно присуство комплемента $^{22}$, док се оба додатна значења по правилу реализују са семантичко-синтаксичком допуном. Најзначајнији допринос оваквог модела анализе је у томе што се, уместо површинског лексикографксог описа омогућава „предвиђање”

\footnotetext{
${ }^{21}$ Увек говоримо о једном глаголу у лескикону са више пројектованих структура аргумената/значења..

${ }^{22}$ На позицији комплемента може се појавити нпр. предлошко-падежна синтагма која није није обавезни део конструкције (оваква релација обележена је испрекиданом линијом).
} 
семантичког понашања глагола на основу његовог прототипског, устаљеног синтаксичког понашања. У наставку рада ћемо овако установљена значења и теоријске закључке проверити на језичкој грађи, тј. на реченичним примерима.

\section{5. АНАЛИТИЧКИ ПРЕДИКАТИ СА ГЛАГОЛОМ КРЕНУТИ КАО КОНСТРУКЦИЈА}

Пошто смо у претходном делу рада приказали значења глагола кренути на нивоу лексикона, сада се можемо окренути дискусији о контекстуализованим значењима, тј. аналитичком предикату као конструкцији. Под језичким контекстом овде подразумевамо оптимални контекст (Прћић 1997: 35), тј. контекст који о посматраном феномену даје реално довољно потребних података што је, у највећем броју случајева, реченица као део текста.

Поред тога што ћемо примерима из релеватнтне литературе и из корпуса савременог српског језика (СрпКор 2013) поткрепити установљене теоријске закључке, овде имамо за циљ и додатно сагледавање конструкције на синтаксичком, те на семантичко-прагматичком нивоу. Будући да су функционална својства $^{23}$ семантичко-синтаксичке допуне лексички несамосталних глагола нешто чему је у досадашњој литератури посвећено највише пажње, те да смо их и сами описали у оквиру класе семантички непотпуних модификатора коју смо предложили у овом раду, овде се тим питањима нећемо додатно бавити. Нама ће функционална својства комплемента бити значајна искључиво спрам њиховог доприноса на нивоу конструкције, на пример у случајевима када присуство или одсуство именске допуне или перфективног глагола у допуни представља формални критеријум разграничавања фазног од модалитетног значења глагола кренути. Додатну пажњу посветићемо и спољашњем аргументу фазног и модалитетног предиката. Темпорална и акционална својства глагола који улазе у састав аналитичког предиката назначена су уколико су релевантна за правилну интерпретацију примера, али се не користе као критеријум поделе значења.

Са друге стране, аспектуална дистинкција префективно/имперфективно је кључна за разликовање фазног од модалног/модалитетног значења: на нивоу конструкције, перфективни лексички глагол одређује доступни тип модификације његовог значења која се може јавити у првом делу аналитичког предиката. Овакав критеријум дефинисан је већ на нивоу лексикона и условљен је лексичким значењем управног глагола (Антонић 2000).

${ }^{23}$ Овде пре свега мислимо на акционалност, те на присуство или одсуство обележја циљ. За детаљну дискусију о овим питањима видети радове Антонић (2000) и Новакова (2005). 


\section{Кренути са фазним значењем}

Уколико се фазни глагол почети јави у перфективном облику, тада означава почетак глаголске ситуације (примери 1а и 1б). Када се фазни глагол почети јави у имперфективном облику, њиме се означава интервал у оквиру почетка ситуације у ком се појављују прва обележја означеног догађаја (примери 2а и 2б). Примери ${ }^{24}$ (1) и (2) преузети су од Кљакић (2020:187), с тим да им је додат глагол кренути са значењем „почети”, како би се показало да два фазна глагола имају истоветна синтаксичка и семантичка својства:

(1) а) У том тренутку сам на његовом лицу видела Ленса. Почела сам/ кренула сам да плачем. Рекла сам, „Нећу, ако ме не натерате.”

б) У питању је била Ки. Почела сам/кренула сам да бринем за Ки све време док је са њим... са њима.

(2) а) Спиди га на тренутак немо посматра, па уместо одговора поново почиње/креће да свира ону живу мелодију.

б) Следећи по реду почиње/креће да се дерња истог тренутка када се Дени нагнуо до прозора.

Као што је већ назначено, имперфективни облик фазног глагола може да указује на појаву првих обележја ситуације или на симултаност са неком другом ситуацијом. Ово значење може се нагласити употребом одредбе као у реченици (2б) где темпорални адвербијал истог тренутка наглашава временску блискост или симултаност радње. Примери (3а) и (3б) илуструју посматраање имперефективности као „дељивости” и перфективности као „недељивости” будући да се ситуација која је представљена као целина не може сегментирати:

(3) а) Узела је писмо и почела/кренула да га цепа, па се предомислила и уместо тога га завукла у бочни џеп фармерки.

б) Узела је писмо и * почела/кренула да га поцепа...

Глагол кренути у примеру (3б) испољава модалитетно значење „намерити, покушати" што је и разлог правилности реченице. Вратићемо се поново оваквим конструкцијама у делу дискусије о модалитетном аналитичком предикату.

Глаголи унутар комплемента са префиксом и суфиксом указују на то да је глаголска ситуација представљена као структура, без обзира на лексичко значење префикса. Оваквим глаголима изражава се имперфективна евентуалност. Пошто је то тако, и њихово понашање на нивоу конструкције једнако је понашању глагола без префикса или суфикса што се види из следећих примера:

${ }^{24}$ Сви анализирани примери преузети су из лингвистичких студија које се цитирају у раду и из електронског корпуса (СрпКор 2013) и доследно су нумерисани уз обавезно навођење извора. Примери поред којих није назначен извор формулисани су ради синтаксичке и семантичке аргументације. 
(4) а) Вратила се књизи и кренула да прелистава странице.

б) *Вратила се књизи и кренула да прелиста странице.

в) Вратила се књизи и кренула да листа странице.

Додатне илустрације употребе глагола кренути са фазним значењем „почети” са аниматним и инаниматним субјектом (пример 8) понуђене су у примерима (5-8) из електронског корпуса СрпКор 2013, Дакле, тип субјекта не утиче на правилност конструкције којом се исказује фазно уначење:

(5) Међутим, кафу није ни стигао да попије јер је убрзо почела пуцњава због чега је кренуо да бежи ка излазним вратима , али га погађа метак и он пада, мада ипак успева да дође до излазних врата (СрпКор 2013: Политика, 22.08.2000.)

(6) А ја сам већ очеличен у бици за опстанак кренуо да играм хокеј у „, Црвеној звезди , и да скијам. Догурао сам до првог тима. (СрпКор 2013: НИН : Недељне информативне новине, 29. април 2002)

(7) Поче га обузимати страх, а то шкоди размишљању. Голум крену да излази из чамца Он шљапну у воду и догаца до обале. (СрпКор 2013: Толкин, Џон Р. Р. Хобит или тамо и натраг)

(8) На том месту има и нешто корова који је кренуо да избија из маховине. (СрпКор 2013: Лаушевић, Жарко. Година прође, дан никада. Београд: Новости, 2011 (Италија).

\section{Кренути са модалитетним значењем}

Примери (9-12) приказују употребу глагола кренути са модалитетним значењима „покушати” и „намерити”:

(9) Десетак секунди пре краја Берић је кренуо да ефектно потврди победу. Међутим, оштро је фаулиран, после чега је руком ударио Ашкрабића и дошло је до туче више играча. (СрпКор 2013: Политика, 08.04.2001.)

(10) А кад је вода почела да кључа и да се пуши, Монморенси је то сматрао изазовом. И баш кад би кренуо да га нападне, неко од нас би му испред носа однео чајник. (СрпКор 2013; Џером К. Џером, Три човека у чамиу.)

(11) У оптужници се наводи да је Плећић после краће препирке устао од стола и окренут леђима према оптуженима кренуо да извади оружје, а тада су Драшковић и Голубовић испалили по два метка Плећићу у леђа. (СрпКор 2013; Политика, 24.02.2001.)

(12) Наставио је да лаже, рекавши да у Сарајеву није ни био. Онда сам кренула да га удавим голим рукама. Момци су га једва спасили из мојих канџи. (СрпКор 2013: Свет, број 211) 
Као што смо напоменули, овај низ примера укључује модалитетно волитивно значење глагола кренути. Оно што на формалном плану одваја овај низ употреба од примера (5-8) је то што се кренути јавља уз перфективни облик глагола у допуни, што нам говори да овде заправо није реч о фазном значењу. Поред тога, глаголи у допуни су семелфактивни, краткотрајни, а таква комбинација на нивоу конструкције је доста честа у модерном језику. Оно што је важно нагласити код овог низа конструкција је то да оптимални контекст који обухвата аналитички предикат пружа информацију о намери или покушају који је пропраћен физичким покретом или физичком радњом. Такво значење овде ћемо окарактерисати као видљиво или манифестовано значење намере/покушаја. У примеру (9) аниматни агенс се креће према голу током фудбалске утакмице, у реченици (10) агенс чини покушај физичког приближавања чајнику, у следећем примеру (11) агенс физички посеже за оружјем, док у примеру (12) агенс креће у физички обрачун са неким. Закључићемо да на семантичком нивоу конструкције манифестовано значење намере заправо представља конфлацију ослабљеног лексичког кренути и његове модалитетне денотације „покушати/намерити”, тј. овде је функционална семантичка модификација коју у конструкцију уноси модалитетни глагол „контаминирана” примарним значењем глагола кренути. Оваква употреба глагола кренути често се наглашава временским, начинским и другим одредбама које се могу јавити унутар аналитичког предиката. Она, међутим, никако није ограничена само на комбиновање са тренутним глаголом у допуни, што се види из примера (13-15) где се кренути јавља са допунама које обухватају трајни телични догађај (остварењье ${ }^{25}$ ):

(13) Испоставило се да није имао превоз за повратак у Краљево, па су тројица браће Битићи кренула да га превезу својим аутомобилом до административне границе са Србијом. (СрпКор 2013: Политика (03.03.2006.))

(14) Они ће процењивати компетентне особе , пре него што, евентуално, крену да намире трошак. (СрпКор 2013: Политика, 07.10.2010.)

(15) И по престанку рада срца, постао (je) потенцијални донатор органа. Међутим, када је екипа лекара кренула да обави операцију вађења органа, пацијент је почео спонтано да дише и да реагује на бол. (СрпКор 2013: www.ртс.рс 13.06.2008.)

25 За ширу дискусију о вендлеријанским типовима лексичког аспекта погледати студије Вендлер 1957, Новаков 2005, Рапапорт Ховав 2008. 


\section{Именска/предлошко-падежна допуна}

Према опису синтаксичких структура који смо понудили у оквиру класе семантички непотпуних модификатора, знамо да фазни глаголи у српском језику осим што своје значење допуњују конструкцијом $\partial а+$ презент или инфинитивом, могу то значење да употпуне и именицом или предлошко-падежном допуном. За разлику од перфективних облика глаголског комплемента који се јављају само уз модалитетна значења, именске и предлошко-падежне допуне јављају се само уз фазна:

(16) Пошто су изгубили шансу да се боре за пласман који води на Европско првенство они ће сада да крену с подмлађивањем репрезентације. (СрпКор 2013: Политика, 12.08.2007.).

(17) У Фонду ПИО упозоравају да будући пензионери не чекају тренутак да раскину радни однос и тек тада крену с прикупљањем папира... (СрпКор 2013: Политика, 12.08.2006.)

У примерима (18-20) фазни глагол кренути означава почетак радње, док именица с предлогом на позицији комплемента у конструкцију уводи пренесено значење метафоричног кретања. Интерпретација метафоричног кретања у конструкцију се уводи или директно, лексичком денотацијом именице (19-20), или индиретктно, интеракцијом предлошко-падежне синтагме са фазним глаголом на нивоу конструкције у оптималном контексту (18):

(18) А што се тиче херметичности, показало се да моји критичари, ако и крену с таквог полазишта, по правилу сасвим лепо сагледају битне идеје... (СрпКор 2013: Политика, 10.12.2007.) - конфлација фазног значења и (метафоричног кретања?)

(19) Мада не треба искључити и крајност: да садашње федералне јединице крену у 21. век по сопственој, самосталној замисли државног устројства. (СрпКор 2013: Политика, 04.01.2001.) - конфлација фазе и метафоричког кретања

(20) Па је неко рекао како у Банату расте шећер. Ипак, многи нису пристајали да оставе камен и крену у бољу сутрашњицу. Тако су се растуриле неке породице. (СрпКор 2013: Политика, 26.09,2000.) интерпретација (почетка) метафоричног кретања намеће се зачењем именице на позицији допуне с предлогом

У примеру (21) јавља се аналитички предикат који се састоји од модалног и фазног глагола. Модални глагол моћи на позицији првог члана аналитичког предиката везује конструкцију ДА+презент која обухвата фазни глагол кренути у значењу „почети” и глаголску именицу (инструментал а предлогом) с предлогом као његову обавезну синтаксичко семантичку допуну. 
(21) То значи да су урађени и одобрени акциони планови и они могу да крену с потписивањем уговора и реализацијом. (СрпКор 2013: Политика, 30.08.2008.)

Овакав инструменатл с предлогом с(а) може се јавити и у имперсоналној „идиоматизованој” реченичној структури са фазним глаголом којим се означава почетак радње (уп. Пипер и сарадници 2005: 238) нпр:

(22) а) Кренуло је лоше с производњом шећера.

б) Пошло је набоље с његовим здрављем.

\section{Субјекат/агенс аналитичког предиката}

Када је реч о разграничаваању фазног и модалитетног значења глагола кренути у саставу аналитичког предиката, вреди се осврнути и на спољашњи аргумент глагола, тј. на синтаксички субјекат. Уколико се ради о интенционалном, аниматном ентитету који може да самостално иницира и проведе радњу, сматра се да је реч о семантичком агенсу (Ивић 2000). За реализацију модалитетног значења какво је „покушати/намерити”, субјекат мора бити семантички агенс и додатно, управни и допунски глагол морају имати идентичан субјекат (ова особина се зове још и идентичност агенса). Ако погледамо примере (23) и (24), видимо да су реченице (23б) и (24б) неправилне.

(23) а) Његов ауто је почео/кренуо да га издаје.

б) *Његов ауто је почео/кренуо да га изда.

(24) а) Сат је почео/кренуо да откуцава поноћ.

б) *Сат је почео/кренуо да откуца поноћ.

Ако се руководимо установљеним синтаксичким критеријумима за разликовање фазног и модалитетног значења, намеће се закључак да се у реченицама (23a), и (24a) глагол кренути мора интерпретирати као фазни. Два су разлога за овакав закључак: први је могућност његове супституције фазним глаголом почети, а други је блокирање његове перфективне допуне као у реченицама (23б) и (24б). Такође, глагол у имперфективном облику не подразумеве обележје +циљ, чије присуство, међутим, на семантичком плану укупне конструкције наглашава интенционалност агенса, а својство +интенционалност даље подразумева + аниматност, па је ово разлог за неправилност/неприхватљивост реченица (23б) и (24б). Но, уколико се на синтаксичкој позицији субјекта појави именица којом се означава део људског тела, прихватљивост и правилност примера делимично се поправља, тачније поправља се употреба са модалитетним кренути (25б): 
(25) а) Његова рука је почела/кренула да је удара.

б) Његова рука је *почела/кренула да је удари.

(26) Руком је кренуо да је удари.

Пример (25a) показује да је фазно значење и даље достпуно, док се из примера (25б) види да је доступно само модалитетно значење, док је реченица са фазним модификатором неправилна. Пошто је то тако, закључићемо да је реченица (25б) правилна само са модалитетним значењем глагола кренути, при чему се енитет који је део људског тела посматра као псеудоаниматни агенс, такав који у реченици поприма семантичке одлике агенса са својствима +аниматни, + интенционални, чији је он саставни део. Део тела може се јавити и у форми објекатског инструментала, као у реченици (26).

Следећи примери из корпуса илуструју јављање именице којом се означава део тела на позицији субјекта:

(27) А Ребеке нигде. Само слика како се згурила под његовом руком што је била кренула да је удари, сва трапава и пијана, и сећање на ударац песнице о фрижидер. (СрпКор 2013: Грифитс, Нил. Патрљак.)

(28) Да је било супротно, Рускиња би стигла надомак победе. Али, Петровој је рука кренула да дрхти. Унервозила се када је наша тенисерка стекла залиху од 40 : 15 (СрпКор 2013: Политика 04.07.2007.)

(29) Чини му се да му је глава још некако бистра, али је једна нога кренула да му отказује, није могао са њом ни лево, ни десно. (СрпКор 2013: Политикин магазин (2002)) ${ }^{26}$

\section{Лексичко-семантичка пресупозција}

Коначно, размотрићемо још један формални, семантички критеријум на основу ког се фазно значење разликује од модалног/модалитетног, а то је лексичко-семантичка пресупозиција, која је обавезна код фазних, али не и код модалних глагола. Вреди је размотрити на нивоу конструкције, где се њен допринос конструкцији може проверити синтаксичким тестом негације:

(30) а) *Почео је да пева/запева, али није запевао.

б) Кренуо је да пева/запева, али није запевао.

в) *Почео је с певањем, али није запевао.

г) *Кренуо је с певањем, али није запевао

Реченица (30а) показује да се лексичко-семантичка пресупозиција о радњи исказаној фазним аналитичким предикатом не може поништити син-

${ }^{26}$ Занимљиво је и то што примери (27-29) обухватају комплементе са различитим акционалним својствима и то семелфактивни глагол (27), активност или процес (28) и итеративна серија (29). 
таксичком негацијом, док је са модалитетним аналитичким предикатом то могуће (30б). Реченице (30в) и (30г) такође показују да је немогуће негирати лексичко-семантичку пресупозицију фазног глагола; у овим примерима додатни разлог за немогућност поништавања лексичко-семантичке пресупозиције (поред фазног значења глагола кренути) је и то што комплемент не може да се разложи на фазне сегменте.

У дискусији о аналитичким предикатима са глаголом кренути на нивоу конструкције, односно у оптималном контексту, учињен је покушај разграничавања фазног и модалитетног значења глагола кренути према формалним синтаксичким и семантичким параметрима, пре свега у погледу припадајуће синтаксичке структуре аргумента, те у погледу њихових релевантних семантичких својстава. Назнаке појединих конфлација значења које смо уочили анализом примера из нашег корпуса потребно је проверити на нивоу целе класе глагола, будући да је немогуће донети коначне закључке на основу само једног или два глагола, тако да ће о томе бити више речи неком другом приликом. Дискусија која је овде приказана поглавито је имала за циљ да нагласи разуђеност значења и конструкција/структура аналитичких предиката са фазним и модалитетним глаголом кренути, те да тиме још једном нагласи оправданост примењеног теоријског модела анализе према ком се лексичко значење глагола у комбинацији са прототипском консталацијом аргумената сматра „генератором” пуног спектра његових употреба, од оних које су дефинисане већ у лексикону, па све до оних које се могу (макар и само повремено) јавити тек на семантичко-прагматичком нивоу.

\section{6. ЗАКЉУЧНЕ НАПОМЕНЕ}

У раду су анализирана два типа аналитичких предиката са глаголом кренути у српском језику, где се тај глагол употребљава као семантички непотпуни фазни или модалитетни модификатор. Применили смо лексичко-пројекционистички модел анализе посматраних значења, како бисмо их што целовитије и систематичније објаснили и разграничили према формалним синтаксичким, структурним и семантичким параметрима. У теоријском делу рада, најпре je успостављена семантичка класа српских глагола којој припада и глагол кренути са својим фазним и модалитетним употребама, (класа семантички непотпуних фазних и модалних модификатора), на основу које је потом изведен укупни лексичко-синтаксички опис глагола кренути, тј. његова лескичка спецификација. У делу рада који обухвата дискусију о језичкој грађи која се користила у раду, учињен је покушај разграничавања додатних значења глагола кренути, на основу претходно дефинисаних формалних критеријума. Будући да смо се у овом истраживању бавили само једним чланом семантичке (под) 
класе глагола коју смо овде успоставили, и то глаголом кренути, неко наредно истраживање могло би се бавити како значењима и употребом осталих њених чланова, тако и другом поткласом укупне класе семантички непотпуних глагола, тј. поткласом копулативних глагола.

\section{ИЗВОРИ}

СрпКор 2013: Душко Витас, Милош Утвић, „Корпус савременог српског језика (СрпКор), верзија СрпКор2013”, Група за језичке технологије Универзитета у Београду, http://www.korpus.matf.bg.ac.rs/korpus (датум приступа: 01.10.2020).

Стевановић 1990: М. Стевановић и др (уред.), Речник српскохрватскога књижевног језика, Друго фототипско издање у 6 књига, Нови Сад: Матица српска.

\section{ЛИТЕРАТУРА}

Антонић 2000: И. Антонић, Аспектуална вредност предикације с фазним/ модалним глаголом на примеру реченице с темпоралном клаузом, Јужнословенски филолог, 56 (1-2): 3-101.

Антонић 2001: I. Antonić, Vremenska rečenica, Sremski Karlovci, Novi Sad: Izdavačka knjižarnica Zorana Stojanovića.

Вендлер 1967: Z. Vendler, Verbs and Times, Philosophical Review, 56, 143-160.

Голдберг 1995: А. E. Goldberg, A Construction Grammar approach to argument structure, Chicago: Chicago University Press.

Голдберг 2006: A. E. Goldberg, Constructions at Work: The Nature of Generalization in Language, Oxford: Oxford University Press.

Звекић Душановић 2011: Д. Звекић-Душановић, Модалност: мотиваииона модалност у српском и мађарском језику, Нови Сад: Филозофски факултет.

Ивић 1961: М. Ивић, О појавама синтаксичке обавезности, Годишњак Филозофског факултета у Новом Саду, књ VI, 180-190.

Ивић 1970: М. Ивић, О употреби глаголских времена у зависној реченици презент с везником да, Зборник Матице српске за филологију и лингвистику, XIII/1, 43-54. 
Ивић 1972: М. Ивић, Проблематика српскохрватског инфинитива, Зборник Матице српске за филологију и лингвистику, XV/2, 115-138.

Ивић 1983: М. Ивић, Лингвистички огледи, Београд: Просвета.

Ивић 2000: М. Ивић, О модификатору улоге АГЕНС, Јужнословенски филолог, LVI/1-2, 463-467.

Ивановић 2012: М. Ивановић, Изражавање акционалности у украјинском и српском језику, [докторска дисертација], Београд: Универзитет у Београду, Филолошки факултет.

Каравесовић 2015: Д. Каравесовић, Нефинитни глаголски комплементи у енглеском и њихови преводни еквиваленти у српском језику, [докторска дисертација], Крагујевац: Филолошко-уметнички факултет.

Кљакић 2020: С. Кљакић, Семантичко-синтаксички међуоднос фазног глагола и комплемента у енглеском и српском језику - контрастивни приcmyn, [докторска дисертација], Нови Сад: Филозофски факултет.

Крстић 2016: М. Крстић, Лексички крњи глаголи и њихова употреба у савременом руском и српском језику, [докторска дисертација], Нови Сад: Филозофски факултет.

Ковачевић 1981: М. Ковачевић, Употреба приједлога преко у српскохрватском стандардном језику, Наш језик, 25/3: 136-158.

Ковачевић 1981: М. Ковачевић, Префиксација и њен утицај на форму и семантику синтагме, Научни састанак слависта у Вукове дане, $16,119-129$.

Левин 1993: B. Levin, English Verb Classes and Alternations: A Preliminary Investigation. Chicago: The University of Chicago Press.

Левин 2000: B. Levin, ”Aspect, Lexical Semantic Representation, and Argument Expression", BLS 26: General Session and Parasession on Aspect, 413-429.

Левин/Рапапорт Ховав 2004: Levin, B. and M. Rappaport Hovav, "The Semantic Determinants of Argument Expression: A View from the English Resultative Construction". In J. Gu'eron and J. Lecarme, (eds.), The Syntax of Time, MIT Press, Cambridge, MA, 477-494.

Миливојевић 2007: Н. Миливојевић, Теличне партикуле у енглеском и перфективни префикси у српском језику - глаголски вид или тип глаголске ситуације?, Годишњак Филозофског факултета у Новом Саду, 32, 397-407. 
Миливојевић 2010: Н. Миливојевић, Синтаксички субјекат као телеолошки агенс глагола емитовања звука у енглеском и српском језику, Годишњак Филозофског факултета у Новом Саду, XXXV-2, 302-312.

Миливојевић 2016: Н. Миливојевић, Конструкциони идиоми у енглеском и српском језику, Е-дисертација 10, Нови Сад: Филозофски факултет. «http://digitalna.ff.uns.ac.rs/sadrzaj/2016/978-86-6065-384-2.〉, 01.10.2020.

Миливојевић 2017: Н. Миливојевић, О структури и класификацији конструкција директивног кретања са глаголима стварања звука у српском језику, Српски језик, XXII, 587-608.

Мразовић/Вукадиновић 1990: П. Мразовић, 3. Вукадиновић, Граматика српског језика за странще. Сремски Карловци, Нови Сад: Издавачка књижарница Зорана Стојановића, Добра вест.

Мразовић 2009: П. Мразовић, Граматика српског језика за странце, Сремски Карловци, Нови Сад: Издавачка књижарница Зорана Стојановића.

Новаков 2005: П. Новаков, Глаголски вид и тип глаголске ситуаиије у енглеском и српском језику, Нови Сад: Футура публикације.

Новаков 2015: П. Новаков, Модални глаголи у енглеском и српском научном дискурсу, у: Мишић Илић, Б. и Лопичић, В. (ур.). Језик, књижевност, дискурс. Језичка истраживања. Ниш: Филозофски факултет, 435-448.

Пипер и др. 2005: П. Пипер и др, Синтакса савременога српског језика, Београд: Институт за српски језик САНУ.

Пипер/Клајн 2013: П. Пипер, И. Клајн, Нормативна граматика српског језика, Нови Сад: Матица српска.

Прћић 2008: Т. Прћић, Семантика и прагматика речи (друго допуњено издање). Нови Сад: Змај, Филозофски факултет.

Пустејовски 1995: J. Pustejovsky, The Generative Lexicon, Cambridge, MA: MIT Press.

Радовановић 1990: М. Радовановић, Списи из синтаксе и семантике, Нови Сад, Сремски Карловци: Издавачка књижарница Зорана Стојановића.

Радовановћ 2004: М. Радовановић, Декомпозиција и универбизација, Зборник Матице српске за филологију и лингвистику, XLVII/1-2, 43-49.

Рапапорт Ховав 2008: M. Rappaport Hovav, "Lexicalized Meaning and the Internal Temporal Structure of Events", In: Rothstein, S. (Ed.), 
Theoretical and crosslinguistic approaches to the semantics of aspect, Linguistics today 110. Amsterdam/Philadelpia: John Benjamins Publishing Company. 13-43.

Станојчић/Поповић 1994: Ж. Станојчић, Љ. Поповић, Граматика српског језика, Београд: Завод за уџбенике и наставна средства.

Стевановић 1969: М. Стевановић, Савремени српскохрватски језик (граматички системи и књижевнојезичка норма) II, Синтакса, Београд: Научна књига.

Степанов/Озер 2016: С. Степанов, К. Озер, Из упоредне граматикологије: конструкције с модалним глаголима у уџбеницима српског/ српскохрватског и немачког језика, у: Костић Томовић, Ј. и др. (уред.), У иарству речи - језици и културе - Зборник у част проф. др Јовану Ђукановићу поводом 85. рођендана. Београд: Филолошки факултет, 168-187.

Фрид 1979: A. Freed, The Semantics of English Aspectual Complementation, Dordrecht: D. Reidel.

Хал/Кајзер 1987: К. Hale and S. J. Keyser, "Register variations in English: some theoretical observations", Journal of English Linguistics 20, 230-248.

Хлебец 1990: В. Hlebec, Aspect, Phases and Tenses in English and Serbo-Croatian . Grazer Linguistische Monographien 8. Graz: Institut für Sprach wissenschaft der Universität Graz.

\section{A LEXICAL-PROJECTIONIST ACCOUNT OF PREDICATE COMPLEX CONSTRUCTIONS WITH THE VERB KRENUTI IN SERBIAN}

\section{Summary}

The paper addresses phase and modal meaning(s) of the verb krenuti in Serbian. When used as a phase verb, krenuti has the denotation "to start" and when it is used as a modal verb its meaning is "to try/to intend". These two additional verbs/meanings will as a rule share almost identical prototypical argument structure as well as similar syntactic and semantic behavior within a language system. The choice of the theoretical model applied in the present analysis is based primarily upon this fact. In order to derive an adequate lexical specification for the verb krenuti on the level of the lexicon we propose a lexical-projectionist theoretical account proposed and outlined by B. Levin (1993) in her study English verb classes and alternations: A preliminary investigation. The theoretical analysis of the research was done in two stages: firstly, a semantic class of lexically incomplete modifiers was established for Serbian, and secondly, based on that class, the full lexical specification 
of the verb krenuti was derived. The proposed novel approach to phase/modal verb complexes' meaning and syntax in Serbian remains a bottom-up model, where the delimiting criteria for meaning differentiation constitutes argument structure on the lexical level enhanced by various co-compositional mechanisms on the level of predicate complex constructions. We believe that the proposed theoretical approach has the necessary explanatory strength to address the issues the paper focuses on. The present theoretical discussion and its conclusions are backed by a sentential corpus extracted from the relevant literature and from the online corpus SrpKor2013.

Keywords: verb krenuti, predicate complex, argument structure, lexical-projectionist model, phase meaning, modal meaning, construction 